\title{
УДК 66.047.59-912
}

\section{Орішкевич С.О. ${ }^{1}$, Собченко Г.О. ${ }^{2}$}

1 - Національний технічний університет Украйни «Київський політехнічний інститут»

2 - Інститут газу НАН України, м. Київ

\section{ВИКОРИСТАННЯ ПСЕВДОЗРІДЖЕННЯ 3 ІНЕРТНИМ ШАРОМ МАТЕРІАЛУ ТА АНАЛІЗ ЙОГО ДОСЛІДЖЕНЬ}

Наведені основні області використання псевдозрідження з інертним шаром матеріалу, представлено аналіз досліджень процесів в псевдозрідженому шарі з інертним шаром матеріалу.

Приведены основные области использования псевдоожижения с инертным слоем материала, представлен анализ исследований процессов в псевдоожиженном слое с инертным слоем материала.

Prime areas of use of fluidization with an inert layer of a material are instanced, the analysis of researches of processes in a fluidized bed with an inert layer of a material presented.

\section{Постановка задачі}

Науковий прогрес людства в сучасних умовах залежить від розроблення та впровадження енергоефективних та екологічних технологій. Саме псевдозрідження $є$ одним з найбільш прогресивних методів здійснення технологічних процесів 3 дисперсною фазою, таких як сушка, гранулювання тощо. Цей метод отримав досить широке поширення в хімічній, нафтопереробній, металургійній, будівельній, харчовій та інших галузях промисловості, що обумовлено рядом його безсумнівних переваг.

Широке впровадження псевдозрідженого шару в багатьох галузях промисловості обумовлено рядом його переваг, до числа яких відносяться інтенсивне перемішування твердих частинок і зріджуючого агента, розвинена поверхня контакту фаз, простота конструктивного оформлення. Завдяки тому, що об'ємна теплоємність твердої фази в тисячу і більше разів вище об'ємної теплоємності газу, частинки псевдозрідженого шару накопичують і переносять з собою велику кількість тепла, навіть при невеликому їх розігріві. Рухомі частинки постійно перемішуються, в результаті чого температура шару вирівнюється майже миттєво. Інтенсивна теплопередача зберігається протягом всього процесу, що забезпечує високу ефективність проведення процесу [1]. 
Дослідження, проведені на установках періодичної і безперервної дії з сушіння твердих матеріалів в псевдозрідженому шарі інертного теплоносія і в потоці повітря, показали, що при одних і тих же температурах і швидкостях повітря швидкість сушки із застосуванням псевдозрідженого шару в 3 - 4 рази вища, ніж при сушінні в потоці чистого повітря.

Актуальною $€$ задача визначення областей використання та особливостей дослідження процесу псевдозрідження 3 інертним шаром матеріалу для подальшої розробки відповідного обладнання.

\section{Виклад основного матеріалу}

Доцільність використання інертного шару підтвердилась рядом експериментів, зокрема в джерелі [2] представлені результати досліджень процесу сушки картону в псевдозрідженому шарі інертного дрібнозернистого теплоносія - шлакові кульки«корольки». Встановлено, що цей метод сушки дозволяє в п'ять - шість разів скоротити час обробки матеріалу, знизити теплові витрати, замінити громіздке обладнання високопродуктивними малогабаритними сушарками.

Збільшення поверхні контакту за рахунок інертних частинок сприяє прискоренню тепло- i масообміну, а безперервне перемішування частинок матеріалу забезпечує вирівнювання температури в шарі, що дозволяє проводити процес сушки швидко і в невеликих робочих об'ємах.

Існує широкий спектр використання псевдозрідження 3 інертним шаром в промисловості.

В харчовій промисловості поширене використання інертних частинок в киплячому шарі для сушки рідких и пастоподібних речовин. Так в [3] представлено технологічний процес сушіння в інертному шарі фторопластових кубиків з ребром 4 - 7 мм. Процес здійснюється наступним чином: висушуваний продукт у вигляді гідроаерозолей подається в апарат через форсунку в бічній стінці циліндричного корпусу і напилюється на інертні частинки. Частинки рухаються в зрідженому шарі, закрученому навколо конічної вставки і формованому похилими лопатями 3 газорозподільною решіткою, встановленою під кутом 21-34 ${ }^{\circ}$ до горизонту в нижній частині апарату. Плівка висушується на поверхні інертного носія зневоднюється і по досягненні заданого вмісту вологи сколюється або стирається.

Широко розповсюджене впровадження технологій термообробки у псевдозрідженому шарі з інертним шаром матеріалу при вулканізації екструдованих монолітних та порожньотілих профілів, рукавних та штучних гумових виробів. [4] Застосування псевдозрідженого шару спрощує проведення температурного контролю, усуває винос нагрівного (або охолоджувального) середовища із заготовками, усуває 
парову сорочку при загартуванні, що також вигідно при витримці нагрітих деталей, внаслідок високої теплоємності та низькій теплопровідності нерухомих частинок шару. Інертний дрібнозернистий матеріал хімічно не взаємодіє з металом, в той час як в солях метал при високих температурах може окислюватися. Поверхня деталі, оброблена в псевдозрідженому шарі, не вимагає очищення або миття. Холодний або підігрітий псевдозріджений шар можна використовувати для загартування матеріалів, при ізотермічній обробці. Використання псевдозрідженого шару перспективне для нагріву чутливих до температури алюмінієвих та інших кольорових сплавів, для термічної обробки тугоплавких металів i сплавів. Значні перспективи використання псевдозрідженого шару для охолодження 3 одержанням менших напруг в деталях, особливо при складних конфігураціях.

Обладнання для вулканізації в псевдозрідженому середовищі характеризується: простотою апаратурного оформлення; можливістю швидкого нарощування довжини вулканізаційної ванни; забезпечує високий коефіцієнт тепловіддачі між середовищем і виробом; дозволяє працювати з різними гумовими сумішами; середовище хімічно інертне, пожежобезпечне, екологічно чисте, нетоксичне і дешеве; досягається швидкий розігрів і охолодження вулканізаційного середовища, висока точність регулювання температур.

Зараз набуває розповсюдження використання апаратів псевдозрідження з інертним шаром в будівельній індустрії. Як приклад, при отримані дрібнодисперсного спученого перліту можливо використовуювати апаратне оформлення з інертним шаром корунду. Спучений перліт володіє високими тепло- та звукоізоляційними властивостями, вогнестійкий, хімічно-інертний, не піддається впливу мікроорганізмів, комах і гризунів. Здебільшого спучений перліт використовують як добавку у високоякісні будівельні матеріали для надання певних властивостей. В роботі [5] представлено результати дослідження та впровадження спучування дрібнодисперсного перліту різних родовищ в апаратах псевдозрідженого шару. Перліт подають в нижню частину апарату, де під дією високих температур $\left(900-1000{ }^{\circ} \mathrm{C}\right)$ відбувається сушка і спучування перліту з подальшим виносом матеріалу з апарату.

Цікавим з наукової точки зору є процес, в якому перліт спучується в киплячому шарі з інертним матеріалом (бінарний шар матеріалу) (рис. 1). Реалізація такого процесу підвищує якісні показники перліту, а також інтенсифікує тепло-масообмін. Технологія псевдозрідження в інертному шарі використовується при спалюванні біомаси. Спалювання біомаси досліджувалося теоретично і експериментально в лабораторних реакторах $з$ псевдозрідженим шаром інертного або каталітичного дисперсного матеріалу в діапазоні температур $400-800^{\circ} \mathrm{C}$. Отримано [6] закономірності макрокінетики горіння в КШ ряду найбільш перспективних натуральних і гранульованих біопалив (деревини, 
гідролізного лігніну, ТПВ, шламів стічних вод), а також торфу, бурого вугілля і горючих сланців. Показана можливість зниження температурного рівня процесу при забезпеченні повного вигоряння летких за рахунок введення в шар алюмооксидного каталізатору. Для обліку двовимірних ефектів (нерівномірності розподілу палива i окислювача за поперечним перерізом топки) запропонований метод, заснований на теорії подібності.

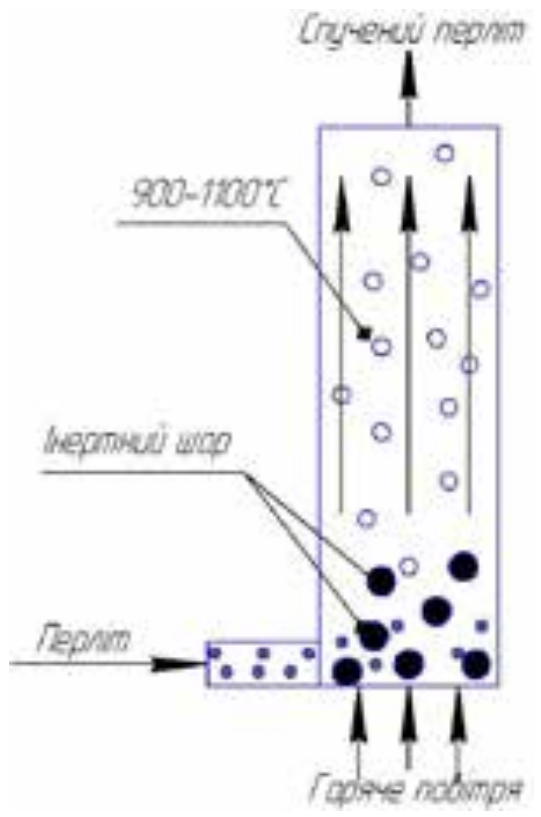

Рис. 1. Схема процесу сушки перліту

В роботі [7] мета полягала в розробці на основі ексергетичного аналізу інженерного методу розрахунку процесу сушіння суспензій і розчинів у киплячому шарі інертного матеріалу та виборі раціональної схеми і апаратурного оформлення цього процесу. Автором розроблено математичну модель та алгоритм розрахунку процесу сушіння розчинів і суспензій у зваженому шарі інертного матеріалу.

В [8] розглянута теплова вулканізація рулонних тканинних матеріалів 3 полімерним покриттям в технологічному процесі виробництва гумотехнічних виробів з використанням псевдозрідження з інертним шаром матеріалу. Практична цінність результатів роботи полягає в тому, що розроблені і доведені до кінцевої комп'ютерної реалізації інженерні методи теплового розрахунку процесів вулканізації полімерних покриттів на тканинах; на базі проведених досліджень запропоновані нові способи теплової вулканізації полімерних покриттів і конструкції апаратів для їх здійснення.

Завданням роботи [9] є розробка типового модуля газорозподільного пристрою апарату щільового типу з регульованим гідравлічним опором кожної щілини, що дасть можливість працювати і з відносно низькими інертними шарами дисперсного матеріалу. 
Автором було запропоновано математичну модель тільки для сушки рідких речовин, для сушки твердих дрібнодисперсних частинок вона не може бути використана.

В статі [10] було розглянуто математичний опис поведінки полідисперсних багатофазних систем. Запропоновано математичну модель, яка описує рух частинок різного розміру в полідисперсному псевдозрідженому шарі. Модель випробувана на обчислювальній техніці і підтверджена експериментально. В модель закладено проблему, суть якої в тому, що просторові схеми дискретизації високого порядку посилює похибку, точніше вона становить вище $60 \%$. Автори статті намагались їі вирішити, але ціль не була досягнута.

В закордонній статі [11] була розглянута проблема сегрегації бінарних сумішей. Запропоновано нову модель для опису процесу псевдозрідження з інертними частинками. Базується ця модель на концепції балансування частинки в бінарному шарі на мінімальному псевдозрідженні. Експериментальні досліди підтвердили математичну модель для опису сегрегації. Але точність розрахунків математичної моделі незадовільна, і тому вона потребує вдосконалення.

В [12] автори досліджують процес сушки зеленого горошку в киплячому шарі 3 інертними частинками, при цьому нагрівають шар комбіновано: потоком гарячого повітря i інфрачервоним випромінюванням. Було побудовано спеціальну експериментальну установку, а також розроблено математичну модель на основі концепції «проникнення двох шарів». Результати, отримані за допомогою запропонованої моделі, були зіставлені 3 експериментальними даними, які були отримані на цій установці. Вони підтверджують адекватність запропонованої моделі. Але адекватність математичної моделі не перевірено при низькому вмісту вологи, що є значним недоліком

Автори статі [13] проводять глибокий аналіз джерел, де розглядаються моделі псевдозрідження полідисперсних суспензій. На основі розглянутих описів процесу було запропоновану власну систему рівнянь для математичного моделювання киплячого шару полідисперсної суспензії. В статі наведено рівняння, графіки та діаграми по результатам досліджень авторів. Певним недоліком запропонованої моделі є те, що вона не враховує різну швидкість частинок.

В роботі [14] викладено результати тестування нової моделі DQMOM, розробленої автором статі Маззеіном. Ця математична модель описує динаміку сегрегації щільних полідисперсних порошків інертних часток. Новизною моделі $є$ те, що вона дозволяє описувати процеси, які відбуваються набагато нижчому рівні ніж представлені в інших джерелах, тобто зменшується похибка між експериментальними результатами та теоретичними. Недолік: якісно результати експерименту та розрахунку вірні, але кількісна точність потребує покращення. 
Авторами статі [15] досліджено процес сушки зеленого горошку та кукурудзи в псевдозрідженому шарі 3 інертними частинками (2,7 мм скляні і сталеві кульки). Наведено математичну модель опису процесу і експериментальні дані. Проведено аналіз отриманих даних, при цьому отримані певні залежності, наприклад, що наявність інертних частинок збільшує швидкість сушіння, але кількість інертного матеріалу не має істотного впливу на швидкість сушіння. Недолік запропонованої моделі є те, що вона накладає певні температурні обмеження при роботі з малою теплопровідністю та великим розміром твердих частинок.

При дослідженні тепло-масообміну в апараті псевдозрідженого шару важливою складовою є дослідження гідродинаміки потоку бінарної суміші шляхом розробки відповідної математичної моделі.

Автори даної статті вважають, що найбільш якісний підхід опису гідродинаміки псевдозрідженого бінарного шару представлено в [16].

Загальним рівнянням прискореного руху полідисперсного матеріалу може вважатися наступне співвідношення повного прискорення частинки і-ї фракції під дією сили гідродинамічного опору, сили тяжіння, ефективної сили зіткнення 3 частинками інших фракцій та ефективної сили тертя частинок об стінку апарату

$$
\begin{gathered}
\rho_{T}\left[v_{i}^{2} \frac{d u_{i}}{d h}+\left(1+u_{i}\right) v_{i} \frac{d v_{i}}{d h}\right]=\frac{3}{4} \frac{\zeta_{i} \rho}{d_{i}}\left(w-v_{i}\right)\left|\omega-v_{i}\right|-g-\frac{3}{4} \rho \omega \sum_{j=i}^{N} E_{j i}\left(1+K_{j i}\right) \\
\cdot \frac{\mu_{i}\left(d_{i}-d_{j}\right)^{2}}{\rho_{i} d_{i}^{3}+\rho_{j} d_{j}^{3}} \frac{v_{j}-v_{i}}{v_{j}}\left|v_{j}-v_{i}\right|+K_{\Gamma} \frac{\pi \lambda_{T P} \rho}{12 D} \cdot \omega^{2} \sum_{i} \frac{\omega_{i}}{d_{i}^{3}},
\end{gathered}
$$

де $u_{i}$ i $\omega_{i}$ - масова частка і вологовміст частинок $i$-ї фракцій.

Коефіцієнт аеродинамічного опору частинок $i$-ї фракції $\zeta_{i}$ зазвичай розглядається як функція критерію $\operatorname{Re}_{i}$ та коефіцієнта форми частинки $f_{\Phi i}$, прийнятого рівним відношенню поверхні частинки до поверхні рівновеликого по об’єму кулі. Там же приводяться значення коефіцієнтів форми для значної кількості різних матеріалів. Представлені експериментальні данні по величинам коефіцієнтів опору частинок. Для частинок з усередненим значенням коефіцієнтів форми $f_{i}=1,15$ можуть бути використані наступні дані:

$$
\zeta=\left\{\begin{array}{l}
25,3 \mathrm{Re}^{-1}+5,25 \mathrm{Re}^{-1 / 3}-0,565 \mathrm{Re}^{-1 / 2} n p u \operatorname{Re}<80 \\
3,54 \operatorname{Re}^{-0,2} n p u \quad 80 \leq \operatorname{Re} \leq 345 \\
1,1 \text { nри } \operatorname{Re}>345
\end{array} .\right.
$$


Коефіцієнт осадження $E_{j i}$ дорівнює ймовірності зіткненню частинок, що мають діаметри $d_{i}$ при $d_{j}$. У граничних випадках в’язкого (індекс « $\left.v »\right)$ і потенційного (індекс « $\rho$ ») обтікання частинок (тобто при $\operatorname{Re} \rightarrow 0$ i $\operatorname{Re} \rightarrow \infty$ ) $E_{j i}^{v}$ та $E_{j i}^{\rho}$ можна визначити в залежності від величини критерію Стокса $S t k=\rho_{j} d_{j}^{2}\left|v_{j}-v_{i}\right| /\left(18 d_{i} \eta\right)$ за наступними наближеним співвідношенням:

$$
\begin{gathered}
E_{j i}^{v}=\left[1+\frac{0,75 \ln \left(4 S t k_{j i}\right)}{2 S t k_{j i}-1,214}\right] \text { при } S t k>0,607 \text { і } 0 \text { при } S t k \leq 0,607, \\
E_{j i}^{p}=\left[S t k_{j i} /\left(S t k_{j i}+0,125\right)\right]^{2} .
\end{gathered}
$$

Для проміжних значень $\mathrm{Re}_{i}$ коефіцієнта осадження можна приблизно вирахувати шляхом інтерполяції значення, отриманих для в'язкого i потенціального режиму обтікання

$$
E_{j i}=\left(\operatorname{Re}_{i} E_{j i}^{p}+60 E_{j i}^{v}\right) /\left(\operatorname{Re}_{i}+60\right) .
$$

В загальному випадку числове значення $k_{n}$ може бути різним в залежності від температури $\theta$ та вологовмісту матеріалу, при цьому по мірі зростання температури $k_{n}$ зменшуватись.

Останній доданок рівняння (1) тотожний деякій ефективності середній силі, що діє на кожну частинку в результаті ударів об стінку апарату. Вираз для сили тертя отримується із відомого співвідношення для втрат тиску внаслідок ударів частинок 3 стінкою при проходженні двофазного потоку через трубопровід

$$
\Delta p_{T}=K_{r} \mu \lambda_{T P}(\Delta h / D) \rho \omega^{2} / 2
$$

де $\Delta p_{T}$ - втрати тиску на тертя потоку сушильного агенту без твердої фази на ділянці висотою $\Delta h$ в апараті діаметром $D$; значення коефіцієнта $K_{r}$ для деяких матеріалів приведено в спеціальній літературі.

Потужність, що втрачається в апараті в наслідок ударів частинок об стінки

$$
\Delta N=\Delta p_{T} \omega \pi D^{2} / 4
$$

Ця потужність може бути виражена через шукану силу тертя частинок об стінку і поперечну складову швидкості 


$$
\Delta N=F_{T} \sum_{i}\left(v_{i} n_{i} \Delta h \pi D^{2} / 4\right),
$$

де $n_{i}$ - рахункова концентрація частинок і-й фракції на ділянці $\Delta h$.

Із двох останніх співвідношень може бути отримано вираз відносно однакової для всіх частинок ефективної сили тертя

$$
F_{T}=K_{r} \mu \lambda_{T P} \rho \omega^{3} /\left(2 D \sum_{i}\left(v_{i} n_{i}\right)\right) .
$$

Число частинок і-й фракції в об'ємі $\Delta h \pi D^{2} / 4$ виражається через масові витрати твердої фази $M_{T}$, долю і-й фракції $\omega_{i}$ і час перебування і-й фракції на ділянці висоти $\Delta h$, що дорівнює $\Delta h / v_{i}$

$$
n_{i}=24 M_{T} \omega_{i}\left(\Delta h / v_{i}\right) /\left(\pi d_{i}^{3} \rho_{T} \Delta h \pi D^{2}\right)
$$

Підстановка співвідношень для $n_{i}$ і витратної концентрації $\mu=M_{T} / G$ у рівність (6) приводить до виразу, відповідному останньому доданку рівняння (1).

\section{Висновки і перспективи подальших досліджень}

Псевдозрідження в інертному шарі є низьковитратним процесом і тому знайшов своє використання в багатьох галузях господарства при проведенні технологічних процесів. Основні труднощі під час моделювання апаратів із псевдозрідженим інертним шаром пов'язані з тим, що розмір найбільших структур у ньому може досягати декількох метрів, тоді як розмір інших, що визначатимуться зіткненнями інертного шару з газом та 3 частинками, не перевищує декількох мікронів, тому моделювання і подальший розрахунок тепло-масообмінних процесів ускладнюються. Сучасні математичні моделі дають можливість подолати проблеми, пов'язані зі складністю опису процесів, які відбуваються в апараті, але не дозволяють досягти певної точності. Тому створення математичних моделей для обробки дисперсних матеріалів у бінарних системах є актуальною задачею.

\section{Перелік посилань}

1. Романков П.Г. Сушка во взвешенном состоянии. / Романков П.Г., Рашковская Н.Б. // Л.: Химия, 1968. - 330 с.

2. Копилова Т.С. Исследование материалов, термообработанных в псевдоожиженном слое инертного теплоносителя: монография / Т.С. Копилова, И.В. Бобров. // Тверь: ТДТУ, 2011. - 124 c. 
3. Куцакова В.Е. Сушка продуктов в аппаратах со встречно-закрученными слоями инертных носителей./ Куцакова В.Е., Маценко Л.В., Искаков М.Х // Мясная индустрия. -2006.- №05, С. 49-52

4. Дворецкий С.И. Техника и технологии псевдоожижения: процессы термообработки и вулканизации / С.И. Дворецкий, В.Н. Королев, С.А. Нагорнов, В.П. Таров. М.: «Издательство Машиностроение-1». -2006. - 232 с.

5. Костогриз К.П. Установка для виробництва теплоізоляційного заповнювача у вигляді порожнистих мікрокульок// Наука та інновації.-2013. -Т. 9. № 5. -С. 48-54.

6. Бородуля В.А. Термохимическая конверсия биомассы в кипящем слое: производство энергии высокотехнологичных материалов / Г.И. Пальчёнок, О.С. Рабинович, Л.М. Виноградов, Н.Г. Хутская, С.В. Василевич, В.В. Корбан / Институт тепло- и массообмена им. А.В. Лыкова НАН Беларуси, Минск: Белорусский национальный технический університет. - 2004. - С. 23 -29.

7. Мухамеджанова В.А. Разработка метода расчета процессов сушки растворов и суспензий на инертном носителе с использованием эксергетического анализа: автореф.дис. к.т.н: 05.17.08 / Мухамеджанова В.А. М: 1998. - 164с.

8. Белянина А.Ю. Интенсификация теплообмена при тепловой обработке полимерных покрытий на тканях : Конструктивная реализация и оценка эффективности, автореф.дис. к.т.н: 05.14.04 / Белянина А.Ю. - Череповец: - 2006. - 184 с.

9. Гензелев М.Б. Моделирование процесса сушки жидких продуктов в псевдоожиженном слое инертных частиц и разработка аппарата с регулируемым гидравлическим сопротивлением газораспределителя, автореф.дис. к.т.н: 05.18.12/ Гензелев М.Б. - Л: 1984. - 171c.

10. Luca Mazzein, New quadrature-based moment method for the mixing of inert polydisperse fluidized powders in commercial CFD codes/ Mazzei Luca, Daniele L. Marchisio, Paola Lettieri // AIChE Journal October 2012. - Vol. 58, No. 10.

11. Alberto Di Renzo, Experimental verification of the particle segregation model predictions for fluidized biomass/inert mixtures/ Renzo Di Alberto, Rossella Girimonte, Vincenzino Vivacqua, Francesco P. Di Maio// The 14th International Conference on Fluidization - From Fundamentals to Products, 01-01-2013.

12. Mowla Dariush, Experimental and theoretical investigation of drying of green peas in a fluidized bed dryer of inert particles assisted by infrared heat source/ Dariush Mowla, Honarvar Bijan, Safekordi Ali Akbar// Iran. J. Chem. Chem. Eng, Vol. 32, No. 01. 2013.

13. Stefan Berres, On mathematical models and numerical simulation of the fluidization of polydisperse suspensions/ Stefan Berres, Raimund Burger, Elmer M. Tory // Applied Mathematical Modelling 29 (2005). - P. 159 - 193. 
14. Luca Mazzein, Segregation dynamics of dense polydispersefluidized suspensions modeled using a novel formulation of the direct quadrature method of moments/ Mazzein Luca// Chemical Engineering Science 101 (2013).

15. M.S. Hatamipour, Drying behaviour of maize and green peas immersed in fluidized bed of inert energy carrier particles/ M. S. Hatamipour, D. Mowla// Trans IChemE, Part C, Food and Bioproducts Processing, 2006, 84(C3): 220 - 226.

16. Бабуха Г.Л. Взаимодействие частиц полидисперсного материала в двухфазных потоках/ Бабуха Г.Л., Шрайбер А.А. - Киев: Наукова думка. - 1972. - 174 с. 